NASZA DERMATOLOGIA Online OUR DERMATOLOGY Online Nil

Competing Interests: None

\section{ROLE OF ORAL ZINC SULPHATE IN WARTS-A PLACEBO CONTROLLED, SINGLE-BLINDED STUDY}

\author{
Iffat Hassan, Taseer Bhat, Hinah Altaf, Farah Sameem, \\ Qazi Masood
}

Department of Dermatology, STD and Leprosy, Government Medical College, Srinagar (University of Kashmir), $J \& K$, India

Corresponding author: Associate Professor Iffat Hassan

hassaniffat@gmail.com

\begin{abstract}
Verrucae (synonym: warts) are one of the most common viral infections of humans in which the most frequently used modalities of treatment involve destruction of the affected area, which does not prevent recurrences and often results in scarring. In the present study oral zinc sulphate, an immunomodulator was evaluated as a treatment modality for warts. A placebo-controlled, single-blinded study was conducted on one hundred OPD patients with various types of verrucae. Fifty patients were put on oral zinc sulphate at dose of $5 \mathrm{mg} / \mathrm{kg}$ for six weeks, while an equal number of patients received placebo for the same duration. In the patients who received oral zinc sulphate, $60.97 \%$ showed complete response at the end of six weeks in comparison to $6.45 \%$ partial response in the placebo group. The resolution of the lesions occurred with restoration of normal epidermal texture with transient alteration in pigmentation.
\end{abstract}

Key words: verrucae; zinc sulphate; human papillomavirus

\section{Introduction}

Verrucae (synonym: warts) are one of the most common viral infections of humans. These are caused by human papillomavirus (HPV). There are approximately 100 genotypes of these DNA viruses. Transmission of HPV occurs most commonly by direct contact with individuals who may be harbouring subclinical or manifesting clinical $\mathrm{HPV}$-associated lesions, or by indirect means such as through contaminated surfaces and objects. Basal keratinocytes of the epidermis which serve as primary targets for HPV infections are exposed to the virus through minor abrasions and infection is promoted by maceration of the epithelia. Recovery from the viral infection is spontaneous in majority of the cases but may take months to years. There is currently no specific antiviral therapy available to cure HPV infection. Existing modalities of treatment including electrocautery, cryotherapy which involve destruction or removal of visible lesions do not prevent recurrences and may even result in scarring.

Zinc, a non-toxic trace element which has been used as an immunomodulator in various dermatological ailments such as leg ulcers, erythema nodosum leprosum (type 2 reaction) and dissecting cellulitis of scalp, has been tried in viral warts with encouraging results [1-3].

\section{Aims and objectives}

To assess the efficacy of oral zinc sulphate in the treatment of viral warts.

\section{Material and Methods}

A total of 100 patients with warts reporting to the dermatology outpatient department of SMHS Hospital (Associated teaching Hospital of Government Medical College Srinagar) over a period of one year, were recruited into the placebo-controlled, single-blinded study. An informed consent was obtained prior to enrolment in the study. The study group included patients with presence of more than ten warts, not on any concurrent therapy for warts since last two months; patients with immunodeficiency connective tissue disorder, pregnancy, lactation were excluded. The patients were examined for the type of warts and their location on the body. A baseline investigation of complete blood count with erythrocyte sedimentation rate was done in all patients. The serum zinc levels could not be estimated because of non availability of the facility.

The study group was randomized into two groups- Group A and Group B by systemic random sampling. Group A received oral zinc sulphate and group B received placebo. The participants in both groups were kept unaware of the type of treatment. 
Fifty patients were given oral zinc sulphate at the dose of $5 \mathrm{mg} / \mathrm{kg} /$ day in two divided doses for a total duration of six weeks. Another 50 patients were given an oral placebo for the same period. Patients were examined after every two weeks for signs and symptoms of regression of the warts.

The response was graded as:

- Complete response:- all warts disappeared

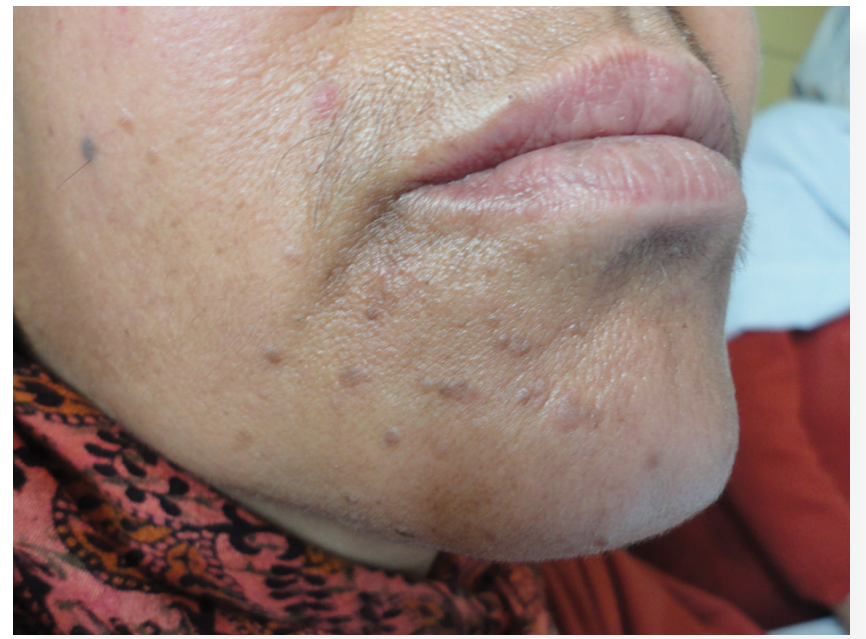

Figure 1. Verruca plana on the chin of a middle aged woman
Partial response:-50\% resolution of warts disappeared

- No response:- none or few warts disappeared

\section{Results (Fig. 1, 2) (Tabl. I-VI)}

Of the 50 patients included in Group A, 41 patients (30 females and 11 males) completed the 6 weeks trial of zinc sulphate whereas in Group B only 33 patients (20 females and 13 males) completed the clinical trial.

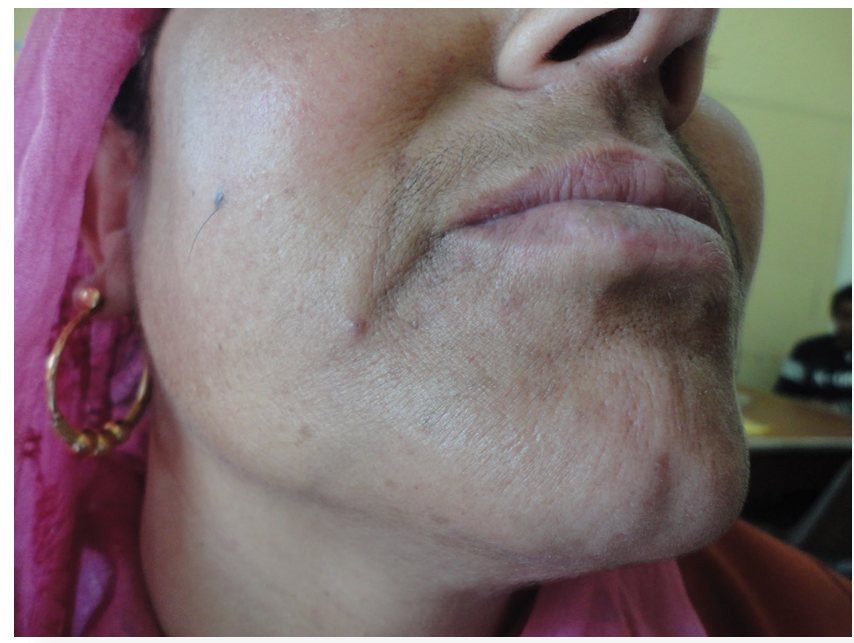

Figure 2. Almost complete clearance at 12 weeks

Clinical description of the study group

\begin{tabular}{|l|l|l|l|}
\hline \multicolumn{1}{|c|}{ Type of warts } & \multicolumn{1}{|c|}{ Group A(n=41) } & \multicolumn{1}{c|}{ Group B $(\mathbf{n}=\mathbf{3 3})$} & \multicolumn{1}{c|}{ p-value } \\
\hline Plane & $22(53.66 \%)$ & $10(30.30 \%)$ & 0.044 \\
\hline Common & $20(48.80 \%)$ & $19(57.60 \%)$ & 0.451 \\
\hline Plantar & $1(2.40 \%)$ & $4(12.10 \%)$ & 0.165 \\
\hline Filiform & $2(4.90 \%)$ & $3(9.10 \%)$ & 0.651 \\
\hline Mucosal & 0 & 0 & \\
\hline
\end{tabular}

\begin{tabular}{|l|l|l|l|}
\hline \multicolumn{1}{|c|}{ Site } & \multicolumn{1}{c|}{ Group A } & \multicolumn{1}{c|}{ Group B } & \multicolumn{1}{c|}{ p-value } \\
\hline Hands & $18(43.90 \%)$ & $15(45.50 \%)$ & 0.894 \\
\hline Face & $26(63.40)$ & $17(51.50 \%)$ & 0.302 \\
\hline Feet & $4(9.80 \%)$ & $8(24.20 \%)$ & 0.093 \\
\hline Perineum & 0 & 0 & \\
\hline
\end{tabular}

\begin{tabular}{l|l|l|}
\hline \multicolumn{1}{|c|}{ Age (years) } & \multicolumn{1}{c|}{ Treatment group } & \multicolumn{1}{c|}{ Placebo } \\
\hline$<20$ & $11(26.82 \%)$ & $10(30.30 \%)$ \\
\hline $20-40$ & $26(63.41 \%)$ & $21(63.63 \%)$ \\
\hline$>40$ & $4(9.75 \%)$ & $2(6.06 \%)$ \\
\hline
\end{tabular}




\begin{tabular}{|c|c|c|}
\hline Study & Age Range (years) & Mean \pm S.D \\
\hline Group A & $13-44$ & $32.15 \pm 8.10$ \\
\hline Group B & $13-38$ & $30.28 \pm 7.15$ \\
\hline
\end{tabular}

\begin{tabular}{|l|l|l|}
\hline \multicolumn{1}{|c|}{ Duration (years) } & \multicolumn{1}{c|}{ Group A } & \multicolumn{1}{c|}{ Group B } \\
\hline$\leq 2$ & $30(73.17 \%)$ & $24(72.72 \%)$ \\
\hline$>2$ & $11(26.82 \%)$ & $9(27.27 \%)$ \\
\hline
\end{tabular}

Table V. Duration of warts in treatment and placebo group p-value $=0.966$ (non-significant)

\begin{tabular}{|c|c|c|}
\hline Response & Group A & Group B \\
\hline Complete response & $25(60.97 \%)$ & 0 \\
\hline Partial response & $6(14.63 \%)$ & $2(6.45 \%)$ \\
\hline No response & $10(24.39 \%)$ & $29(93.54 \%)$ \\
\hline
\end{tabular}

The mean age of participants in the placebo group was 30.28 \pm 7.15 years and in the treatment group was $32.15 \pm 8.10$ years (Tabl. IV). Patients who responded completely to oral zinc sulphate developed mild to moderate pruritus, erythema and an initial increase in the size of the warts within two to three weeks of starting the treatment. Mild transient epigastric pain was reported by $6 \%$ of patients but did not require cessation of treatment. A total of 26 patients $(60.97 \%)$ showed complete resolution of the warts; $6(14.6 \%)$ patients showed partial response; there was no response to treatment in $10(24.3 \%)$ patients. In the placebo group there was partial response in $2(6.45 \%)$ patients while $29(93.5 \%)$ patients showed no response to placebo (Tabl. VI). The patients who responded completely to oral zinc sulphate were regularly followed up for a period of six months with no evidence of recurrence of the warts.

\section{Discussion}

Viral warts are an extremely common benign condition caused by infection of epidermal cells with the human papillomavirus (HPV), resulting in cell proliferation. A thickened warty papule on the skin or mucous membrane is the typical clinical presentation. The most common sites involved are the hands, feet and the face. Two large population based studies found prevalence rates of $0.84 \%$ and $12.9 \%$ respectively $[4,5]$. Prevalence rates are higher in children and young adults. Studies in school population have shown prevalence rates of $12 \%$ in $4-6$ years old and $24 \%$ in $16-18$ years old $[6,7]$.

The current treatment for warts involves the physical destruction of infected cells which sometimes results in scarring. Common therapeutic modalities for viral warts include cryotherapy, keratolytics, topical immunotherapy with contact sensitizer, oral cimetidine, antimitotic agents, carbon dioxide laser, electrosurgery, photodynamic therapy, intralesional injection of antigens and topical immune response modifiers. None of these modalities is universally effective [8].

Zinc is an important element that is found in every cell in the body. More than 300 enzymes in the body need zinc in order to function properly. It is also essential for the proper functioning of the immune system. In zinc deficiency, the function of the macrophages and $\mathrm{T}$ cells is impaired with fifty percent reduction in leucocytes and $40-70 \%$ reduction in antibody-mediated and cell-mediated immunity [9-11]. The addition of zinc to a culture system results in polyclonal stimulation of lymphocytes [12]. Zinc has been previously used as an immunomodulator in a number of dermatological diseases such as erythema nodosum leprosum and dissecting cellulitis of scalp [13]. Al-Gurari FT et al. used oral zinc sulphate at a dosage of $10 \mathrm{mg} / \mathrm{kg}$ for a total period of two months in the treatment of viral warts with a cure rate of $87 \%$ [14].

The present study was done to find out the efficacy of oral zinc sulphate at lower doses and for a shorter duration in order to minimize side effects and to improve compliance respectively. Of the patients who completed the six weeks therapeutic trial of oral zinc sulphate, $60.9 \%$ showed a complete response and $14.6 \%$ a partial response in comparison to partial response of $1.61 \%$ in the placebo group [p-value $=0.000$ (Highly significant)]. Resolution of warts occurred without any scarring but was associated with transient hypo as well as hyper pigmentation.

In a study by Stefani et al. adverse effects reported by the patients treated with zinc sulfate were nausea, vomiting and diarrhoea. These adverse effects were attenuated by dividing the total dose into three daily doses and taking the medication together with meals [15]. Only mild epigastric pain $(6 \%)$ was observed in our patients which did not require interruption of treatment. 
This could possibly be due to a lower dose of zinc sulphate used in our study.

This study confirms the role of oral zinc sulphate as a systemic treatment modality for viral warts with the advantage of being non-invasive, non scarring, and having the potential of preventing recurrences.

\section{REFERENCES}

1. Black MM, Gawkroger DJ, Seymour CA, Weismann K: Metabolic and nutritional disorder. In: Textbook of Dermatology. Champion RH, Burton DA, Breathnack SM. eds 6th edn. Oxford: Blackwell Science. 1998;59:2577-673.

2. Wilkinson EAJ: Does oral zinc aid the healing of chronic leg ulcer? Arch Dermatol. 1988;59:2577-673.

3. Bern B,Venge P, Ohman S: Perifolliculitis capitis abscedens et suffodeins (Hoffman). Complete healing associated with oral zinc therapy. Arch Dermatol. 1985;121:1028-30.

4. Johnson ML, Robert J: Skin conditions and related need for medical care among persons 1-74 years. US Department of health education and welfare publication. 1978;1660:1-26.

5. Beliaeva TL: The population incidence of warts. Vestn Dermatol Venerol. 1990;2:55-8.

6. Williams HC, Pottier A, Strachan D: The descriptive epidemiology of warts in British schoolchildren. Br J Dermatol 1993;128:504-11.
7. Kilkenny M, Merlin K, Young R, Marks R: The prevalence of common skin conditions in Australian school students: Common, plane and plantar viral warts. Br J Dermatol. 1988;138:840-5.

8. Park HS, Choi WS: Pulsed dye laser treatment for viral warts:A study of 120 patients. J Dermatol. 2008;35:491-8.

9. Fraker PJ: Zinc deficiency and immune function. Arch Dermatol. 1987;123:1699-701.

10. Russell RM, Suter PM: Vitamin and trace mineral deficiency and excess. In: Harrison's principles of Internal Medicine Longo D1, Fauci AS ,Kasper DL, Hauser SL, Jameson JL, Loscalzo J eds 18th edn. New York: Mc Graw-Hill. 2012:594-605.

11. Fraker PJ: Interrelationship between zinc and immune function. Fed Proc. 1986;45:1475.

12. Wirth JJ, Fraker PJ, Kierszenbaum F: Zinc requirement for macrophage function: Effect of zinc deficiency on uptake and killing of a protozoan parasites. Immunology. 1989;68:114-9.

13. Mahajan PM, Jadhar VH, Patki AH: Oral zinc in recurrent erythema nodosum leprosum: a clinical study. Indian J Lepr. 1994;66:51-7.

14. Al-Gurari FT, Al-Waiz M, Sharque KE: Oral zinc sulphate in the treatment of recalcitrant viral warts: randomized placebo controlled clinical trial. Br J Dermatol. 2002;146:423-31.

15. Stefani M, Bottino G, Fontenelle E, Azulay DR: Efficacy and comparison between cimetidine and zinc sulphate in the treatment of multiple and recalcitrant warts. An Bras Dermatol. 2009;84:23-9. 16. Yaghoobi R, Sadighha A, Baktash D: Evaluation of oral zinc sulfate effect on recalcitrant multiple viral warts: A randomized placebo-controlled clinical trial. J Am Acad Dermatol. 2009;60:7068 .

Copyright by Iffat Hassan et al. This is an open access article distributed under the terms of the Creative Commons Attribution License, which permits unrestricted use, distribution, and reproduction in any medium, provided the original author and source are credited. 